that the out-patient care available in Community Mental Health Centres cannot.' In addition to specific psychiatric treatment, mental hospital residents received housing, food, money, general medical care and work and social activities. People with chronic impairments will require active long-term support and advocacy aimed at meeting these needs if they are to avoid living an isolated and marginal existence similar to that in the back wards of the worst hospitals.

Secondly, when deinstitutionalization is pushed to its limit by eliminating mental hospital backup, a small proportion of patients remain who cannot adequately be catered for by the full range of acute psychiatric treatments and community alternatives to hospitalization. ${ }^{2}$ These patients tend to accumulate inappropriately in the district general hospital in-patient unit. They include some elderly demented patients with severe behavioural disturbance: the mentally handicapped mentally ill; those with brain damage and assaultative behaviour: and a small number of psychotic patients who are either dangerous to themselves or others or behave in socially unacceptable ways. Specialized units should be set up for these patient groups.

Thirdly, economic pressures have prompted many American States to encourage the development of profitmaking private facilities for the care of long-term patients at the expense of public psychiatric services. The quality of care provided in such facilities is extremely difficult to monitor, and their emergence adds to the fragmentation of an already complex system. ${ }^{3}$

Fourthly, the Community Mental Health Centre Movement, which was initially a central component in the process of deinstitutionalization, proved to be based on misguided premises about the nature of psychiatric disorder and over-optimistic assertions about the efficacy of treatment. CMHCs have proved extremely vulnerable to changes in funding policy, and have by and large failed to provide for the most severely disturbed and disabled patients. ${ }^{4}$

Finally, although the American experience has thrown up a number of extremely innovative model programmes for the management of the long-term mentally ill within the community, the generalizability of the available research evidence is dubious. ${ }^{5}$ Model programmes have not provided blueprints for a national pattern of services, at least partly because of inadequate funding.'

If we are to develop new patterns of psychiatric services in Britain, we must do so in the light of local conditions, evaluating the developments as we go along. This is of course far from an original insight."

King's College Hospital

Frank Holloway

\section{London SE5}

\section{REFERENCES}

'Borus, J. F. (1981) Deinstitutionalization of the chronically mentally ill. New England Journal of Medicine, 305, 339-342.

2Gudeman, J. E. \& Shore, M. F. (1984) Beyond deinstitutionalization: A new class of facilities for the mentally ill. New England Journal of Medicine, 311, 832-836.

3Mollica, R. F. (1983) From asylum to community: The threatened disintegration of public psychiatry. New England Journal of Medicine, 308, 367-373.
4BACKRACH. L. L. (1982) Assessment outlines in community support systems: Results, problems and limitations. Schizophrenia Bulletin, 8, 39-60.

SWING. J. K. (1972) Principles of evaluation. In Evaluating a Community Psychiatric Service (eds. J. K. Wing and A. M. Hailey). Oxford University Press.

\section{Countertransference-apathy}

DeAr Sirs

May I draw attention to the addition of a comma in my letter (Bulletin. May 1985, 9, 105-106) which seems to be a typographical error. Though the sentence still makes sense, perhaps more sense than I intended, no break was intended between 'countertransference' and 'apathy'. One of the major problems therapists face in relationships with the most damaged of personalities is, I submit, countertransferenceapathy, if I may hyphenate.

Stratford Road Day Centre

Geoff LAYTON

Birmingham

\section{On Bryon Gysin}

DeAr Sirs

On the coffee table of a psychiatrist friend I saw the May 1985 issue of your Bulletin. Glancing over the contents listing I was amazed to see the name of Bryon Gysin. All the more so in that your Scribe's Column made no reference to Gysin (Bulletin, May 1985, 9, 101-102).

It seems that you expected your readers to be familiar with the name though, in my experience, Gysin is a little known figure and where he is known at all, it is among the cut-up conspirators. And I would not have expected to find the membership of the Royal College of Psychiatrists among that company.

Gysin has always been an interesting figure for me and I would like to know how your readers would know of him. Has your Bulletin had an article on him? Please solve the mystery.

\section{Milton House}

Graham Dawes

Elmington Estate, London SE5

[This letter was shown to Ezra, who replied: 'I must congratulate Graham Dawes on recognizing that my verse was produced by the William Burroughs cut-up technique and not by the College computer, as many members have heretofore believed. The reason for the title was that the dream was produced using the methodology of Gysin rather than that of Freud. Until recently, as a follower of Adler, I have not dreamed at all.'-Eds.]

\section{A Limerick}

At a meeting of poets and shrinks I certainly had a few drinks On this auspicious day

I really can't say Which of them had the most kinks. 